Dept. of Animal Med., Infectious Dis.,

Faculty of Vet. Med., Assiut Univ., Assiut Egypt, amazaitoun@yahoo.com.

\title{
CLINICAL MASTITIS CAUSED BY STAPHYLOCOCCUS AUREUS IN DAIRY BUFFALOES
}

(With 8 Tables, 4 Figures and 10 Photographs)

\author{
By
}

\section{A.M.A. ZAITOUN}

(Received at 18/9/2008)

\section{التهاب الضرع الاكلينيكي المسبب بميكروب المكور العنقودي الذهبي

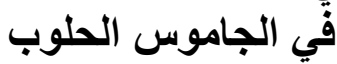

\section{أحمد زيتـون}

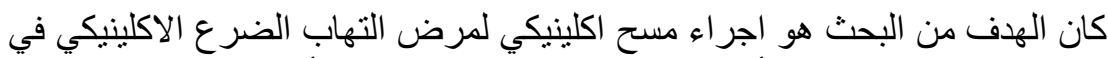

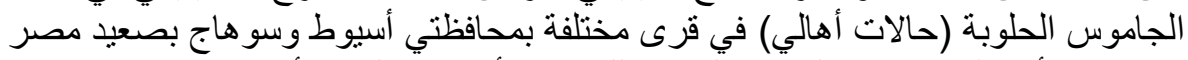

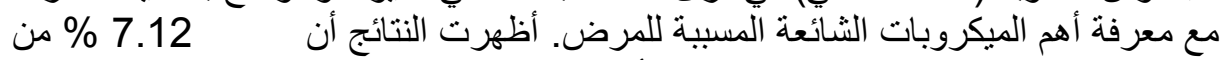

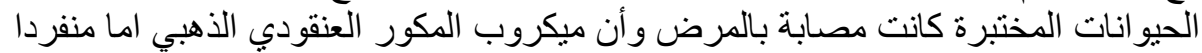

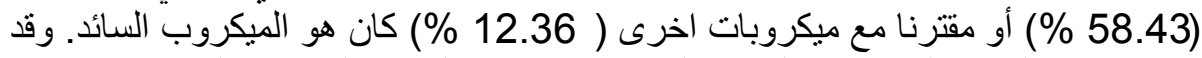

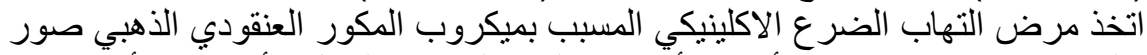

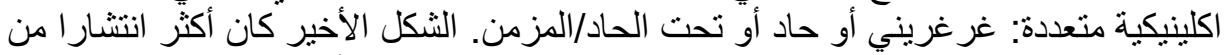

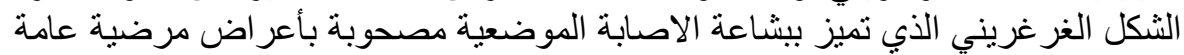

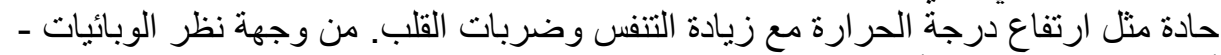

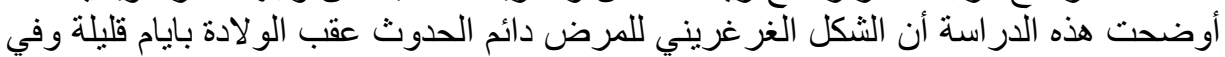

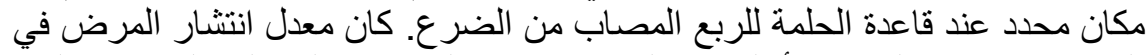

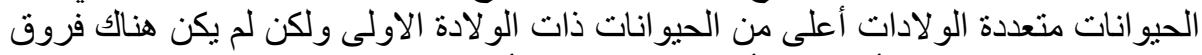

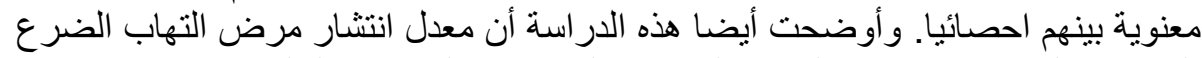

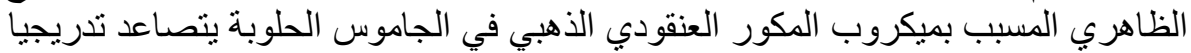

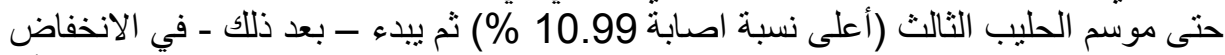

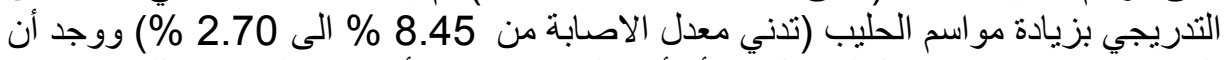

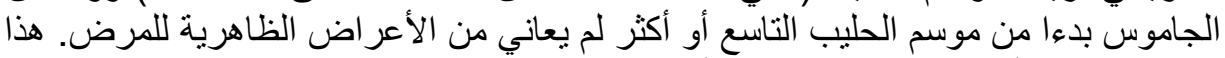

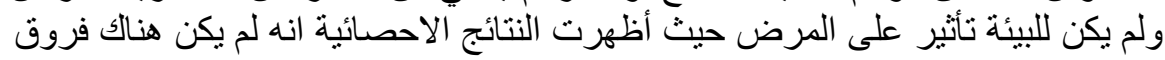

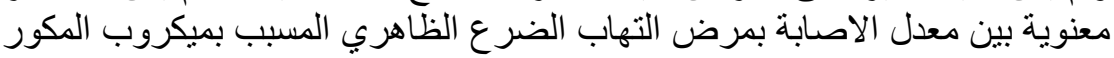

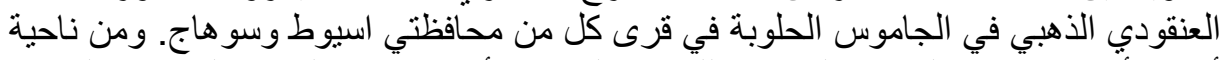

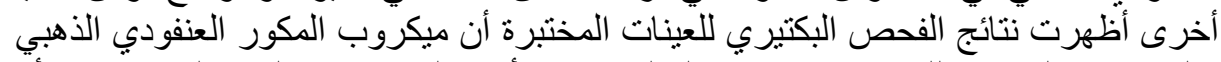

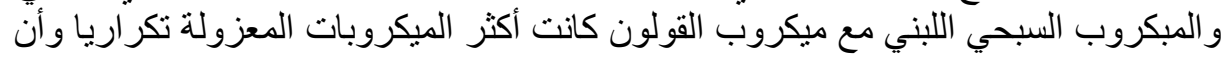




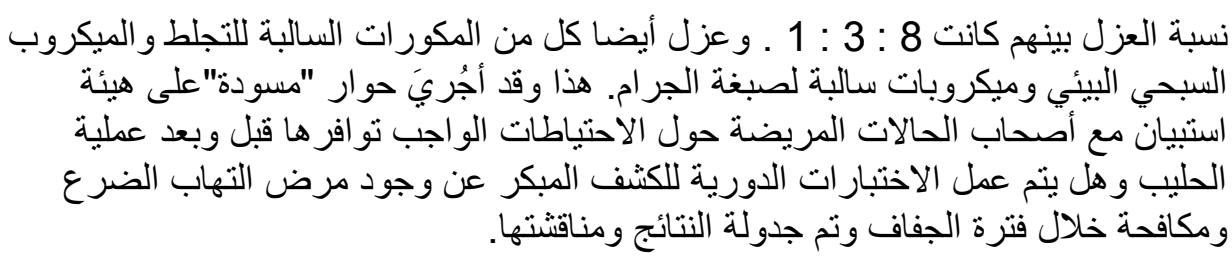

\section{SUMMARY}

Mastitis of private dairy buffaloes located on different villages of Assiut and Sohag Governorates, Upper Egypt was clinically surveyed and the most common mastitis pathogens were encountered. This survey revealed that $7.12 \%$ of the examined cases were clinically infected and Staphylococcus aureus either alone (58.43\%) or coupled with other pathogens $(12.36 \%)$ was the predominant etiologic agent of clinical mastitis. Staphylococcus aureus mastitis (SAM) of dairy buffaloes has various clinical forms: gangrenous, acute, subacute and/or chronic. The later form was more prominent than the gangrenous form, which had seriousness effects on the affected and the neighboring unaffected quarters of the afflicted cases, with severe systemic illness including pyrexia, tachycardia, hyperpnea. Clinical descriptions of the diseased buffaloes with SAM are illustrated and discussed. Epizootiologically, the gangrenous form of SAM occurred in few days post buffalo-calf delivery and usually situated at the base of the teat (annular fold). The prevalence rate of clinical mastitis in multiparous buffaloes was mathematically higher than primiparous animals; however this difference was statistically insignificant $(\mathrm{P}>0.05)$. The prevalence rate of clinical mastitis of the examined animals was primarily increased by increasing the lactation numbers till the third lactation season (peak infection rate, $10.99 \%$ ) and thereafter gradually decreased by subsequent increasing in the lactation numbers (range of infection rate, $8.45 \% \sim 2.70 \%$ ) and dairy buffaloes with more than 9 lactation seasons were found with no signs of clinical mastitis. From an ecological point of view, the prevalence rate of clinical mastitis of private buffaloes located in villages of Assiut and of Sohag Governorates was statistically insignificant $(\mathrm{P}>0.05)$. Bacteriologically, Staphylococcus aureus $(60.58 \%)$, Streptococcus agalactiae $(23.08 \%)$ and Escherichia coli $(7.69 \%)$ were the predominant frequently isolates and the ratio between them was 8: 3: 1, respectively. However, coagulase negative staphylococci (5.77 \%), Streptococcus uberis $(1.92 \%)$ and unidentified Gram negative bacteria $(0.96 \%)$ were also isolated. A rough 
questionnaire with the buffaloes' owners was carried out. The questions were turned on the premilking and postmilking sanitary measures, and periodical testing against mastitis and dry-period therapy, and the results were tabulated and discussed.

Key Word: Buffaloes, Staphylococcus aureus-mastitis, Clinical, Bacteriology, Epizootiology, Ecology.

\section{INTRODUCTION}

Mastitis remains incriminated as one of the critical problems of the dairy animals causing dramatic economic losses during the lactation season. These losses are primarily due to lower milk yield, reduced milk quality, and higher costs of treatment and control (Detilleux, 2004, Almeida et al., 2007 and Palanivel et al., 2008). Microorganisms causing mastitis of dairy animals are numerous, but mastitis pathogens of dairy ruminants can be categorized as environmental (Escherichia coli and Streptococcus uberis) or contagious (streptococcus agalactiae and Staphylococcus aureus) depending on their primary reservoir (environment versus infected mammary gland) (Bramley, 1996, Riffson et al., 2001 and Reddy et al., 2007). Mastitis caused by contagious pathogens appears to be more prevalence than the environmental mastitis (Haltia et al., 2006 and Riekerink et al., 2006 and Reddy et al., 2007). Staphylococcus aureus is an important etiologic agent of contagious mastitis (Pyörala and Pyörala, 1997, Tollersrud et al., 2006 and Ali, et al., 2008).

Buffalo appears to be the first animal for milk yield rather than meat production in Egypt and approx. 65\% (or may be more) of the daily milk production in Egypt is obtained from dairy buffaloes (Metry, 1996). The majority of Egyptian buffaloes' population is apparently still under the farmer's hand (private cases) rather than that those kept on farms for milk and meat production. However, the majority of literature on mastitis of dairy animals at Upper Egypt is focused on Friesian cows and on buffaloes that located on farms (El-Gamal, 1989 and Seddek et al., 1999). The published reports on incidence of mastitis in dairy buffaloes at south Egypt are scarce and no sufficient data are available on udder health in freshly calved buffalo-heifers (primiparous), although clinical mastitis has frequently been observed (personnel communications with veterinary practitioners). Furthermore, the frequent field observations in various veterinary clinics at different 
villages of south Egypt indicate that diagnosis of mastitis depends principally on the clinical inspection of the grossly affected mammary quarter(s) and thereafter treated by an available wide-spectrum antimastitis drug without detection of mastitis pathogen, which consider the cornerstone in mastitis' treatment and control. Moreover, the selected anti-mastitis drug was mostly chosen based on the experience of veterinarians and/or owners. Such defects are ascribed principally to poor laboratory facilities of the bacteriological examinations in territories. On the other hand, not all owners accept the bacteriological analyses of the milk of their affected buffaloes to minimize the costs of laboratory diagnoses and they irrationally treated the clinically affected cases. The present work was carried out to clear-up the prevalence rate and the various forms of clinical mastitis in private dairy buffaloes at different lactation seasons (different ages), and to indicate the most common mastitis pathogen(s) responsible for intramammary infections of dairy buffaloes kept under farmers' hands.

\section{MATERIALS and METHODS}

\section{1 - Animals:}

During the period of investigation, June 2002 to September 2007, a total number of 1250 dairy buffaloes (private cases) at different villages of Assiut and Sohag Governorates, Upper Egypt were clinically inspected and their mammary glands were carefully examined for detection of gross udders and milk abnormalities. The diseased cases with clinical signs of mastitis were categorized into three forms, peracute, acute, subacute/chronic with and/or without systemic involvements. The examined buffaloes are milked manually twice daily and are categorized primarily to primiparous $(\mathrm{n}=187)$ and multiparous $(n=1063)$ buffaloes. The later animals are grouped according to their lactation seasons into 11 groups, from the $2^{\text {nd }}$ to $13^{\text {th }}$ lactation season (Table 3). History of previous mastitis or reduction of milk yield due to known and/or unknown cause, prior treatment and lactating data were serially enrolled. On the other hand, the effect of the environment on the prevalence of clinical mastitis of the examined animals located on villages of Assiut $(n=503)$ and Sohag $(n=747)$ Governorates was monitored. During the collection of milk samples a rough questionnaire with the owner has been carried out. The questionnaires were focused principally on the following topics: a) periodical testing of mastitis by an indirect field test during lactation season, b) pre-milking procedures 
such as udder washing and teat disinfection, c) post milking teat dipping with an antimicrobial dip, and d) dry period therapy at the end of lactation season.

\section{2 - Samples collection and culturing procedures:}

Each mammary quarter of the examined dairy buffalo with sign of clinical mastitis (udder and/or milk abnormalities) was aseptically sampled and the intramammary secretion (approx. $25 \mathrm{ml}$ ) was collected in sterile screw-capped bottle. The collected sample was primarily incubated at $37{ }^{\circ} \mathrm{C}$ for overnight. Post incubation, the sample was centrifuged and half milliliter of the suspended-sediment was cultured into sterile tube containing $2.5 \mathrm{ml}$ brain heart infusion broth supplemented by $10 \%$ of inactivated horse serum and incubated for 24 hours, and thereafter platted onto $10 \%$ sheep's blood agar medium. On the other side, another half millimeter of the suspended-sediment was also taken and platted directly on sheep's blood agar plates. The cultured plates were aerobically incubated at $37{ }^{\circ} \mathrm{C}$ for $24-48$ hours. The suspected colonies were picked up, purified, and morphologically and biochemically identified as the protocol described by Newbould (1990). The remained samples were stored at $-20^{\circ} \mathrm{C}$ for further investigation.

The isolated staphylococcus aureus strains were identified according to the criteria prescribed by Cole, Jr. (1990). These criterions included the followings; hemolysis, clamping factor, tube-coagulase, pigment, catalase, DNase, sugars fermentation for aerobic and anaerobic acid production, and novobicin resistant/sensitive tests. All coagulase positive Staphylococcus aureus isolates were tested to acriflavin (SigmaAldrich) tolerance test as described by (Capurro et al., 1999). Furthermore, the isolated strains of Staphylococcus aureus were also tested by dry spot StaphyTect (Oxoid).

\section{3 - Statistical analyses:}

Prevalence (\% affected) of clinical mastitis of the examined primiparous and multiparous buffaloes was determined by conventional procedures.

The relationship between the lactation seasons (age of animal) of the examined dairy buffaloes ( $X$, independent variable) and the prevalence of clinical mastitis (\% affected, $Y$ dependent variable) was linearly studied using simple linear regression, and correlation coefficient (r) was mathematically calculated (Chatfield, 1970). On the other hand, $F$-test (ANOVA, analysis of variance) used to clear-up the 
significance or the insignificance of the applied regression line as described by Chatfield (1970).

The prevalence rates of clinical mastitis of the examined multiparous buffaloes at different lactation seasons was pooled and a comparison between the susceptibility rate of primiparous and multiparous buffaloes to clinical mastitis was statistically carried out using Chi square on the form of the following equation (Milton and Tsokos, 1983).

$\mathrm{X}^{2}=\left[\sum\left(\mathrm{O}^{2} \div \mathrm{E}\right)\right]-\mathrm{N}$

Where, $\mathrm{o}$ is the observed, $\mathrm{E}$ is the frequencies expected, $\mathrm{N}$, total number.

Furthermore, the collected data of the susceptibility rate of primiparous and multiparous buffaloes was also analyzed statistically by $F$-test—one-way ANOVA (Chatfield, 1970).

\section{RESULTS}

\section{1 - Clinical findings:}

The clinical examinations of the dairy buffaloes $(n=1250)$ at different lactation seasons revealed that $89(7.12 \%)$ cases showed gross signs of clinical mastitis (Table 1 and 2, Fig. 1) in various forms associated with and/or without systemic reactions (Table 1). Of these clinically mastitis buffaloes, $63(70.79 \%)$ cases yielded Staphylococcus aureus, either alone or mixed with others, in their mammary secretions (Fig. 4).

Nine cases $(10.11 \%)$ of the clinically diseases buffaloes with mastitis $(n=89)$ showed signs gangrenous form of mastitis. The affected quarters were swollen and reddish in color and then they become deeply pinkish with blue cast and they were softer, insensitive, and cold. Thereafter they were sloughed leaving a well demarcated hemorrhagic line (blackish border) surrounding the affected area (Photo A). Simple squeezing of the affected area elaborated minute air-bubbles. The affected quarters of gangrenous mastitis cases secreted little amounts of watery brownish secretions tinged with blood and contained shreds of tissues. The unaffected quarters of the gangrenous mastitis case were also diffusely pinkish in color (Photo B) and warm. However, their milk appears to be normal grossly, and the owners declared that the milk yield was remarkably reduced. On one case, when the affected quarter is gently squeezed, it is accidentally sloughed leaving dark hemorrhagic 
borders. However, there was no remarkable pain was noticed on the affected buffalo. The supra-mammary lymph nodes of the gangrenous mastitis were impalpable. In all gangrenous cases, it was found that the gangrenous area occurred in teat just below the annular fold of the affected quarter, and the neighboring portions of the udder (Photo A). All cases with gangrenous mastitis were recently calved buffaloes (from 2 to 8 days post calf delivery). Two cases $(22.22 \%)$ of the gangrenous mastitis buffaloes $(\mathrm{n}=9)$ were primiparous while the remainders $(77.78 \%)$ were multiparous. The majority ( 8 of $9,88.9 \%$ ) of the gangrenous mastitis cases showed remarkable systemic reactions. These reactions included elevation of body temperature (Mean \pm S.E., $40.67 \pm$ $\left.0.10{ }^{\circ} \mathrm{C}\right)$, increased the cardiac beats, $(70.12 \pm 0.94)$, increased the respiratory rates, rapid and shallow $(32.33 \pm 0.61)$ and the ocular mucous membranes were congested and the scleral vessels were obviously engorged with blood. There were three gangrenous cases were shivered and reluctance to move except under forcing, due to the painful action of the gangrenous lesion and their ruminal motilities were dramatically static.

There were two cases (Table 1) showed acute form of Staphylococcus aureus-mastitis with classic cardinal signs of inflammation particularly hotness and redness with remarkable signs of pain (Photos C, D, E and F). The redness coloration was diffusely throughout the udder However, signs of systemic reactions could not be noticed and supramammary lymph nodes were impalpable. Moreover, closure examinations of these cases revealed that the apexes of their teats were obviously abraded / eroded and partially covered by brownish scab.

Eleven cases $(12.36 \%)$ of the clinically mastitic buffaloes showed signs of acute form without marked signs of systemic reactions and their supramammary lymph nodes could not palpated and their milk secretion was remarkably reduced and apparently similar to the normal milk with fine cheesy flakes (Table 1), where both Staphylococcus aureus coupled with Streptococcus agalactiae were isolated. Clinical description of the clinically mastitis cases were summarized in Table 1.

On the other side, $41(65.08 \%)$ cases of the Staphylococcus aureus-mastitis $(\mathrm{n}=63)$ of the examined buffaloes have subacute/chronic form (Table 1) and the affected udder appear to be normal and their supramammary lymph nodes were impalpable. Their milk was varies from normal appearance to thick viscous secretion 
(Photos G, H, I and J). Udders of three cases were firm and indurate with large nodules (Photo $\mathrm{H}$ ).

\section{2 - Bacteriological examinations:}

Frequent distribution of the bacteriologically isolated mastitis pathogen were illustrated (Table 1 and Fig. 3), which shows that Staphylococcus aureus is the predominant isolate followed by Streptococcus agalactiae, Escherichia coli, coagulase negative staphylococci and streptococcus uberis. On the other hand, the frequent distribution of clinical mastitis cases $(\mathrm{n}=89)$, which yielded Staphylococcus aureus either alone or coupled with others pathogens was figured (Fig. 4), which indicated that 63 (70.79\%) cases of the clinically mastitis buffaloes $(\mathrm{n}=89)$ yielded Staphylococcus aureus in their mammary section.

\section{3 - EPIZOOTIOLOGY and Statistical analyses:}

The overall prevalence of the clinical mastitis of the examined dairy buffaloes was tabulated (Table 2). The detailed prevalence of the examined dairy buffaloes at different lactation seasons were illustrated in Table 3 and Fig. 1, which indicate that the prevalence of mastitis was gradually ascended to the peak level (third lactation season) and thereafter gradually descended. Statistically, results of the linear relationship (simple linear regression) between lactation season and prevalence (\% affected) of clinical mastitis was illustrated (Table 3 and Fig. 2) and the regression formula and the correlation coefficient were illustrated (Fig. 2), which indicate strong negative correlation $(\mathrm{r}=-0.92)$ (Table 4). Prevalence rate and statistical analyses (Chi square and oneway-ANOVA) of clinical mastitis in primiparous and multiparous buffaloes were tabulated (Table 3, 5 and 6). Ecologically, results of the prevalence of clinical mastitis of the examined dairy buffaloes in villages of Assiut and Sohag Governorates were statistically tabulated (Table 7). 


\section{Table 1: Clinical and bacteriological examinations of the diseased buffaloes with signs of clinical mastitis $(n=89)^{*}$.}

\begin{tabular}{|c|c|c|c|}
\hline \multirow{2}{*}{$\begin{array}{l}\text { Number of } \\
\text { clinical } \\
\text { mastitis cases. }\end{array}$} & \multicolumn{2}{|c|}{ Clinical status of the diseased udder } & \multirow{2}{*}{$\begin{array}{l}\text { Predominant } \\
\text { mastitis } \\
\text { pathogen }(\mathrm{s})^{*}\end{array}$} \\
\hline & Mammary gland & Mammary secretion & \\
\hline $9(10.11 \%)$ & Gangrenous mastitis. & $\begin{array}{l}\text { Odorless reddish and/or brownish } \\
\text { bloody secretion contain shreds or } \\
\text { flaks of clots }\end{array}$ & $\begin{array}{l}\text { Staphylococcus } \\
\text { aureus }\end{array}$ \\
\hline $2(2.25 \%)$ & $\begin{array}{l}\text { Acute mastitis, pinkish } \\
\text { discoloration of the } \\
\text { affected udder was } \\
\text { remarkable }\end{array}$ & $\begin{array}{l}\text { Thick creamy stick or Yellowish } \\
\text { white (pale) in color with unpleasant } \\
\text { odor }\end{array}$ & $\begin{array}{l}\text { Staphylococcus } \\
\text { aureus }\end{array}$ \\
\hline $24(26.97 \%)$ & $\begin{array}{l}\text { Subacute mastitis, the } \\
\text { affected quarter(s) was } \\
\text { semi-indurate and no } \\
\text { marked signs of pain was } \\
\text { detected during palpation }\end{array}$ & $\begin{array}{l}\text { Light secretion; lose the characteristic } \\
\text { odor and the bright white-color of } \\
\text { buffalo's milk. Fifteen milk samples } \\
\text { were white with yellowish cast }\end{array}$ & $\begin{array}{l}\text { Staphylococcus } \\
\text { aureus }\end{array}$ \\
\hline $11(12.36 \%)$ & $\begin{array}{l}\text { Subacute mastitis, the } \\
\text { affected quarter(s) was } \\
\text { painless, swollen and } \\
\text { semi-firm similar to a bag } \\
\text { over-filled with } \\
\text { compressed spongy } \\
\text { materials }\end{array}$ & $\begin{array}{l}\text { Odorless watery secretion with fine } \\
\text { sticky white clots similar to sandy } \\
\text { particles that settled down on the } \\
\text { bottom of the collected bottle within } \\
\text { few minutes }\end{array}$ & $\begin{array}{l}\text { Staphylococcus } \\
\text { aureus }\end{array}$ \\
\hline $6(6.74 \%)$ & $\begin{array}{l}\text { Chronic mastitis, and the } \\
\text { affected quarters have firm } \\
\text { nodules }\end{array}$ & $\begin{array}{l}\text { Thick whitish odorless viscous } \\
\text { secretion with unpleasant odor }\end{array}$ & $\begin{array}{l}\text { Staphylococcus } \\
\text { aureus }\end{array}$ \\
\hline $11(12.36 \%)$ & $\begin{array}{l}\text { Acute mastitis with classic } \\
\text { cardinal signs of } \\
\text { inflammation }\end{array}$ & $\begin{array}{l}\text { White with yellowish cast in color } \\
\text { with unpleasant odor with little } \\
\text { amount of fine floccules }\end{array}$ & $\begin{array}{l}\text { Staphylococcus } \\
\text { aureus } \\
\text { Streptococcus } \\
\text { agalactia }\end{array}$ \\
\hline $9(10.11 \%)$ & $\begin{array}{l}\text { Acute mastitis with classic } \\
\text { cardinal signs of } \\
\text { inflammation }\end{array}$ & $\begin{array}{l}\text { Similar to normal milk with fine } \\
\text { clotted (cheeses) particles and lose the } \\
\text { characteristic milky odor }\end{array}$ & $\begin{array}{l}\text { Streptococcus } \\
\text { agalactiae }\end{array}$ \\
\hline $7(7.86 \%)$ & $\begin{array}{l}\text { Acute mastitis, the affected } \\
\text { quarter(s) could not } \\
\text { touched due to sever pain } \\
\text { and vigorousness of } \\
\text { animal }\end{array}$ & $\begin{array}{l}\text { Reddish in color containing fine } \\
\text { brownish flakes. The characteristic } \\
\text { odor of the milk was lost. }\end{array}$ & Escherichia coli \\
\hline $2(2.25 \%)$ & $\begin{array}{l}\text { Acute mastitis, the affected } \\
\text { quarter was painful and } \\
\text { swollen }\end{array}$ & $\begin{array}{l}\text { White-yellowish in color with little } \\
\text { amount of fine clotted (cheeses) milk }\end{array}$ & $\begin{array}{l}\text { Streptococcus } \\
\text { uberis } \\
\text { Coagulase } \\
\text { negative } \\
\text { Staphylococci } \\
\end{array}$ \\
\hline $4(4.49 \%)$ & $\begin{array}{l}\text { Acute mastitis with classic } \\
\text { cardinal signs of } \\
\text { inflammation }\end{array}$ & $\begin{array}{l}\text { Light mammary secretion, yellowish- } \\
\text { white in color with no odor }\end{array}$ & $\begin{array}{l}\text { Streptococcus } \\
\text { Agalactiae } \\
\text { Coagulase negative } \\
\text { staphylococci }\end{array}$ \\
\hline $1(1.12 \%)$ & $\begin{array}{l}\text { Acute mastitis, the affected } \\
\text { quarter was painful and } \\
\text { pinkish in color }\end{array}$ & $\begin{array}{l}\text { Whitish watery secretion contains } \\
\text { bloody flakes with unpleasant odor }\end{array}$ & $\begin{array}{l}\text { Escherichia coli } \\
\text { Unidentified Gram } \\
\text { negative bacteria }\end{array}$ \\
\hline $3(3.37 \%)$ & $\begin{array}{l}\text { Chronic mastitis, the } \\
\text { affected quarters showed } \\
\text { fibrosis and indurations }\end{array}$ & $\begin{array}{l}\text { Colorless, odorless serous secretion } \\
\text { was dripped after frequent vigorous } \\
\text { stripping }\end{array}$ & $\begin{array}{l}\text { Mastitis pathogens } \\
\text { could not be } \\
\text { isolated }\end{array}$ \\
\hline
\end{tabular}

*: Eighty nine $(7.12 \%)$ of the examined buffaloes $(n=1250)$ are clinically positive to mastitis in various forms

**: The bacteriological examinations focused on the most common mastitis pathogens. 
Table 2: Prevalence (\% affected) of clinical mastitis (CM) of the examined primiparous and multiparous dairy buffaloes.

\begin{tabular}{|l|l|l|l|l|l|}
\hline $\begin{array}{l}\text { Number of } \\
\text { examined } \\
\text { buffaloes }\end{array}$ & $\begin{array}{l}\text { Number of } \\
\text { diseased cases } \\
\text { with CM }\end{array}$ & \multicolumn{2}{|l|}{ Primiparous buffaloes } & \multicolumn{2}{l|}{ Multiparous buffaloes } \\
\cline { 3 - 6 } & $\begin{array}{l}\text { Number of } \\
\text { cases with CM }\end{array}$ & $\begin{array}{l}\text { Number of } \\
\text { affected } \\
\text { quarters }\end{array}$ & $\begin{array}{l}\text { Number of } \\
\text { cases with } \\
\text { CM }\end{array}$ & $\begin{array}{l}\text { Number of } \\
\text { affected } \\
\text { quarters }\end{array}$ \\
\hline 1250 & $89(7.12 \%)$ & $14(1.12 \%)$ & $17(0.34 \%)$ & $75(6.00 \%)^{\mathrm{a}}$ & $91(1.82 \%)$ \\
\hline
\end{tabular}

Table 3: Prevalence rate of clinical mastitis (CM) of dairy buffaloes at different lactation seasons and values of regression formula.

\begin{tabular}{|c|c|c|c|c|c|}
\hline $\begin{array}{l}\text { 志 } \\
\text { 吾 }\end{array}$ & $\begin{array}{l}\text { Lactation } \\
\text { season } \\
\text { (Independent } \\
\text { variable, } X \text { ) }\end{array}$ & $\begin{array}{l}\text { Number } \\
\text { of animals }\end{array}$ & $\begin{array}{l}\text { Number } \\
\text { of animal } \\
\text { with CM }\end{array}$ & $\begin{array}{l}\text { Prevalence rate } \\
\text { (Dependent } \\
\text { variable, } Y \text { ) }\end{array}$ & $\begin{array}{l}\text { Regression formula } \\
\text { and value }(\mathrm{X} \cdot \mathrm{Y}) \text { per } \\
\text { each lactation season } \\
{[Y=A+B x]} \\
{[Y=10.95+(-0.98 x)]}\end{array}$ \\
\hline $\mathrm{P}^{*}$ & 1 & 187 & 14 & $\begin{array}{ll}0.079 \quad(7.49)^{\mathrm{a}} \\
\end{array}$ & 9.98 \\
\hline \multirow{11}{*}{ M } & 2 & 215 & 18 & $0.084 \quad(8.37)$ & 9.00 \\
\hline & 3 & 191 & 21 & $\begin{array}{ll}0.1099 & (10.99)\end{array}$ & 8.03 \\
\hline & 4 & 190 & 17 & $0.0895 \quad(8.45)$ & 7.05 \\
\hline & 5 & 147 & 8 & $0.0544 \quad(5.44)$ & 6.07 \\
\hline & 6 & 117 & 5 & $0.0427 \quad(4.27)$ & 5.10 \\
\hline & 7 & 75 & 3 & $0.04 \quad(4.00)$ & 4.12 \\
\hline & 8 & 52 & 2 & $0.0385 \quad(3.85)$ & 3.14 \\
\hline & 9 & 37 & 1 & $\begin{array}{ll}0.027 & (2.70)\end{array}$ & 2.17 \\
\hline & 10 & 19 & 0 & $\begin{array}{ll}0 & (0.0)\end{array}$ & 1.19 \\
\hline & 11 & 11 & 0 & $(0.0)$ & 0.21 \\
\hline & 13 & 9 & 0 & $(0.0)$ & -1.79 \\
\hline
\end{tabular}

P: Primiparius $(\mathrm{n}=187) \quad$ M: Multiparous $(\mathrm{n}=1063)$

*: There is no significance difference $(P>0.05)$ in the prevalence rate of $\mathrm{CM}$ in $\mathrm{P}$ and M groups.

a: The numbers between parentheses in this column are the percentage of infection with clinical mastitis of buffaloes per each lactation season

Table 4: Analysis of variance (ANOVA) for confidence of linear regression.

\begin{tabular}{|l|c|c|c|c|}
\hline $\begin{array}{l}\text { Source of } \\
\text { variance }\end{array}$ & $\begin{array}{c}S S \\
\text { Sum of Squares }\end{array}$ & $D f$ & $\begin{array}{c}M S \\
\text { Mean squares }\end{array}$ & $F$ \\
\cline { 1 - 4 } Regression & 124.450 & 1 & 124.450 & \multirow{2}{*}{$55.10^{* *}$} \\
\cline { 1 - 4 } Residual & 22.586 & 10 & 2.259 & \\
\cline { 1 - 4 } Total & 147.036 & 11 & & \\
\hline
\end{tabular}

df: Degree of freedom $\quad * *$ : Highly significance $(P<0.01)$

Calculated $\mathrm{F}=52.15 \quad$ Tabulated $F_{0.05}=4.96 \quad$ Tabulated $F_{0.01}=9.65$ 
Table 5: Statistical analysis (Chi square) of prevalence of clinical mastitis $(\mathrm{CM})$ in primiparous and multiparous dairy buffaloes

\begin{tabular}{|l|c|c|c|}
\hline Animal & Diseased cases (CM) & Non-diseased cases & Total \\
\hline $\begin{array}{l}\text { Primiparous } \\
\text { buffaloes }\end{array}$ & 14 & 173 & 187 \\
\hline $\begin{array}{l}\text { Multiparous } \\
\text { buffaloes }\end{array}$ & 75 & 988 & 1063 \\
\hline Total & 89 & 1161 & 1250 \\
\hline
\end{tabular}

The calculated $\chi^{2}=0.045 \quad$ Tabulated $\chi_{0.05}^{2}=3.84$

Table 6: Statistical analysis (One-way ANOVA) of prevalence of clinical mastitis $(\mathrm{CM})$ in primiparous and multiparous dairy buffaloes

\begin{tabular}{|l|c|c|c|c|}
\hline Source of variance & $\begin{array}{c}S S \\
\text { Sum of Squares }\end{array}$ & Df & $\begin{array}{c}M S \\
\text { Mean squares }\end{array}$ & \multirow{2}{*}{0.045} \\
\cline { 1 - 4 } Between groups & 0.003 & 1 & 0.003 & \\
\cline { 1 - 3 } Within groups & 82.660 & 1248 & 0.006 & \\
\cline { 1 - 4 } Total & 82.663 & 1279 & & \\
\hline
\end{tabular}

df: Degree of freedom

Calculated $\mathrm{F}=0.045$

Table 7: Statistical analysis (Chi square) of prevalence of clinical mastitis (CM) of dairy buffaloes located in villages of Assiut and Sohag Governorates, Upper Egypt.

\begin{tabular}{|l|c|c|c|}
\hline Governorate & Diseased cases $(\mathrm{CM})$ & Non-diseased cases & Total \\
\hline Assiut & $31(6.16)$ & 472 & $503(\mathrm{na})$ \\
\hline Sohag & $58(7.74)$ & 689 & $747(\mathrm{nb})$ \\
\hline Total & $89(7.02)$ & 1161 & $1250(\mathrm{n})$ \\
\hline
\end{tabular}

The numbers between parentheses are the percentage of infection with CM per each Governorate na: Number of the examined buffaloes at Assiut Governorate $\mathrm{nb}$ : Number of the examined buffaloes at Sohage Governorate $\mathrm{n}$ : Total number of buffaloes The calculated $\chi^{2}=1.165$ Tabulated $\chi^{2}{ }_{0.05}=3.84$

Table 8: Results of questionnaire with buffaloes' owners $(n=1013$ person) at different villages of Assiut and Sohag Governorates, Upper Egypt.

\begin{tabular}{|l|c|c|}
\hline \multicolumn{1}{|c|}{$\begin{array}{c}\text { Question turn-on } \\
\text { (Do you know ...?) }\end{array}$} & Yes I know & No, I don't know \\
\cline { 2 - 3 } $\begin{array}{l}\text { Premilking precautions } \\
\text { (washing of udder) }\end{array}$ & $41(4.05 \%)$ & $972(95.95 \%)$ \\
\hline $\begin{array}{l}\text { Postmilking teat dipping with } \\
\text { an antimicrobial dip }\end{array}$ & $11(1.09 \%)$ & $1002(98.91 \%)$ \\
\hline $\begin{array}{l}\text { Dry period therapy at the end } \\
\text { of lactation }\end{array}$ & $0 *$ & $1004(99.11 \%)$ \\
\hline $\begin{array}{l}\text { Periodical testing of mastitis } \\
\text { during the lactation season by } \\
\text { indirect test such as California } \\
\text { mastitis test }\end{array}$ & $9(0.89 \%)$ & \\
\hline
\end{tabular}

*: Unfortunately, no one has knowledge on dry period therapy and the owners ascribe this lack to the economic costs and the dairy buffaloes are drying abruptly. 


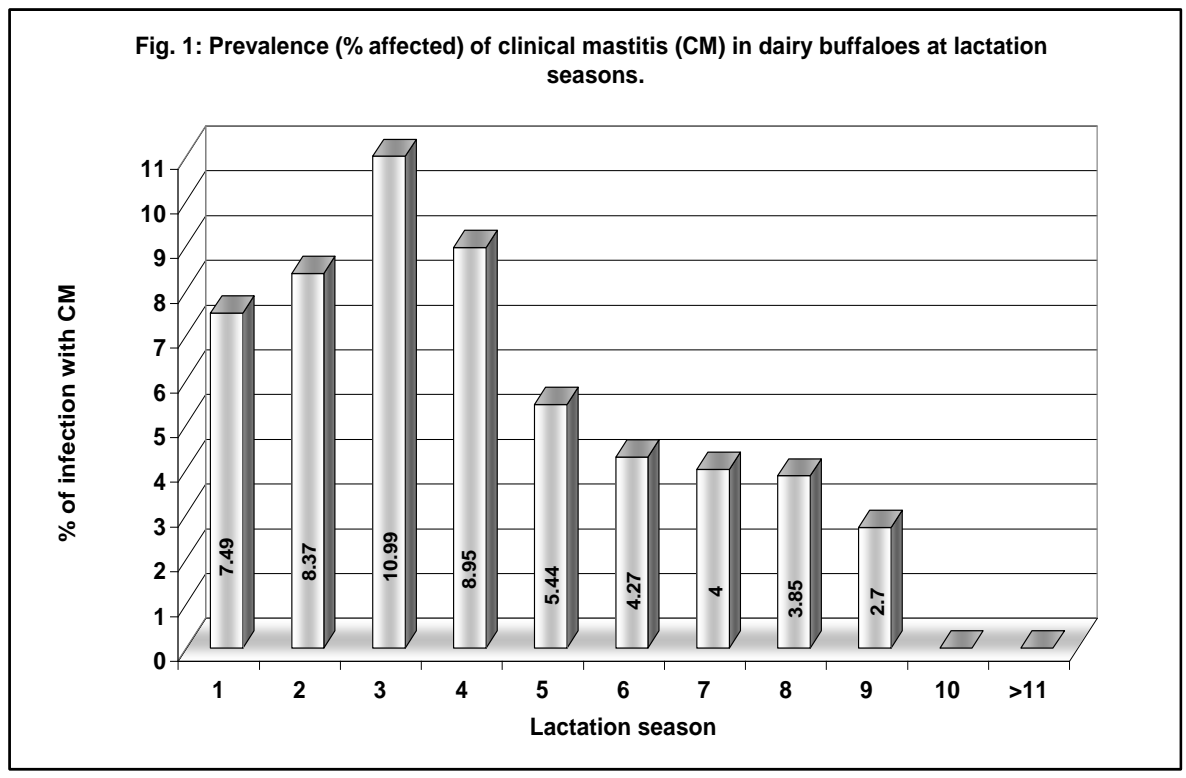

Fig. 2: Linear regression between age of the examined buffaloes (lactation seasons) and prevalence (\% affected) of clinical matitis (CM)

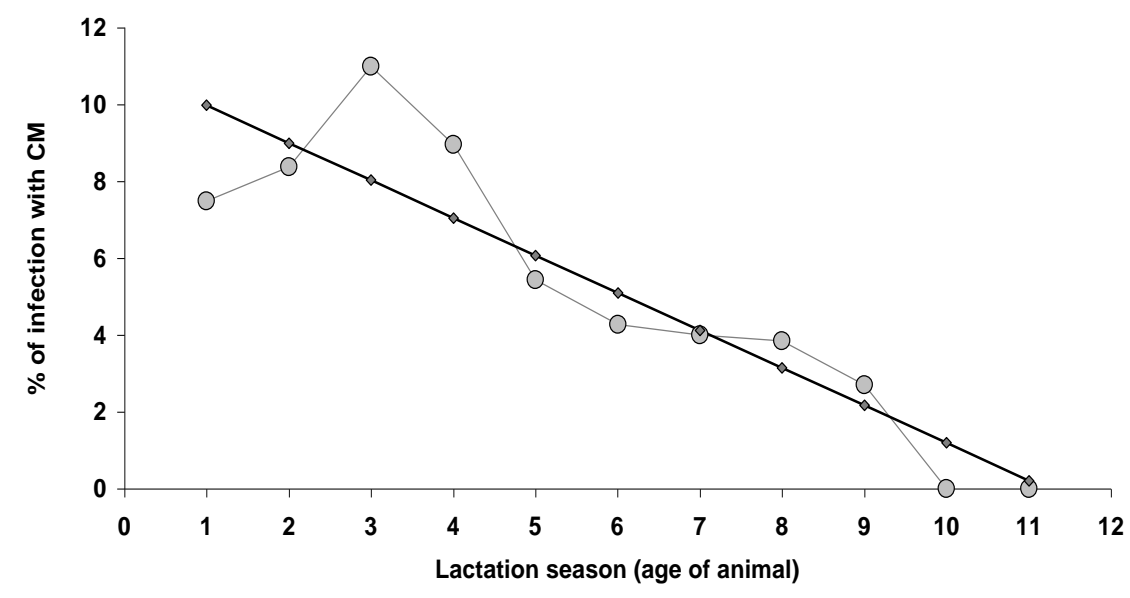

$-\circ \%$ of $\mathrm{CM} \quad \sim$ Simple linear regression, Regression formula; $Y=10.95+(-0.98 x)$. Correlation coefficient; $r=-0.92$ 
Fig. 3: Frequent (\%) distribution of the isolated mastitis pathogens ( $n=104$ isolates) from dairy buffaloes showed signs of clinical mastitis ( $n=89$ cases)

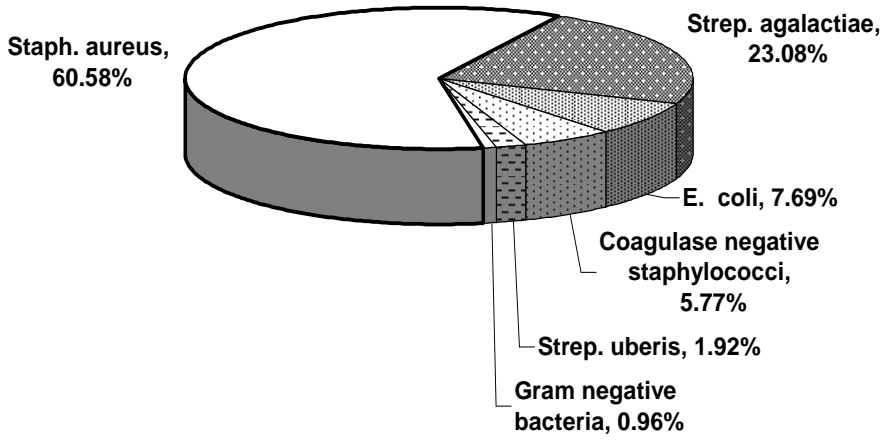

Fig. 4: Frequent distribution of the clinical mastitis cases $(n=89)$ yielded Staphylococcus (Staph) aureus either alone or coupled with other pathogens in their mammary secretion

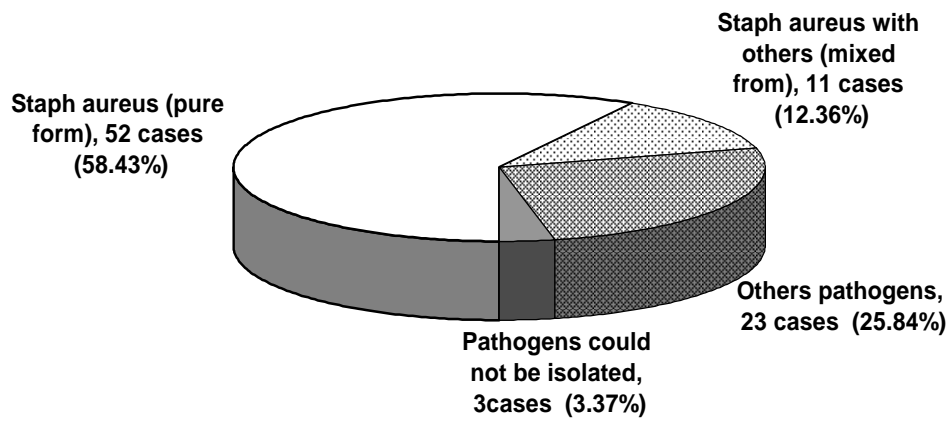


Photos A and B: Gangrenous form of Staphylococcus aureus mastitis of dairy buffaloes. The affected quarter is sloughed leaving a well demarcated hemorrhagic line (blackish border). The neighboring unaffected quarters are diffusely pinkish in color.

Photos C and D: Acute nongangrenous form of Staphylococcus aureus mastitis, note the diffusely pinkish coloration of the affected udder

Photos E and F: Acute form of Staphylococcus aureus mastitis of dairy buffaloes, show the reddish coloration of the infected udder particularly the reared right quarter (cardinal signs of acute inflammation), and the apex is abraded. (Photo F) 
Photo G: Subacute form of Staphylococcus aureus mastitis in one quarter. Note, the enlargement of the left reared quarter and has a pendulous shape.

Photo H: Chronic form of Staphylococcus aureus mastitis. Note the nodular formation along the apex of teat to the base of the quarter.

Photos I and J: Chronic form of Staphylococcus aureus mastitis yielded thick sticky viscous discharge. 


\section{DISCUSSION}

The clinical survey in harmonization with the bacteriological examinations of the examined dairy buffaloes indicated that $7.12 \%$ of the examiners were clinically positive to mastitis in variable degrees and the majority of the bacteriologically tested samples yielded Staphylococcus aureus either alone $(58.43 \%)$ or coupled with others mastitis pathogens $(12.36 \%)$. These results elucidate that the isolation rate of Staphylococcus aureus is reached up to $70.79 \%$ alarming that this pathogen is an etiologic agent of major concern in clinical mastitis of dairy buffaloes located in villages of Assiut and Sohag Governorates, Upper Egypt. Pyörala and Pyörala (1997), Tollersrud et al. (2006), Reddy et al. (2007) and Ali et al. (2008) concluded that Staphylococcus aureus is an important cause of intramammary infection of dairy ruminants and more than $30 \%$ of bovine clinical mastitis was due to this infection. Mastitis caused by Staphylococcus aureus may forms a major problem for dairy animals due to the following probable reasons. (a) Staphylococcus aureus mastitis tends to commence with an acute clinical episode, which subsequently develops to become a chronic infection (Anderson, 1982). (b) The bacteriological cure rates of the infected dairy animals with Staphylococcus aureus mastitis after antibiotic therapy is dramatically low ranged from $9 \%$ to $35 \%$ (Owens et al., 1997; Deluyker et al., 1999 and Waage et al., 2000) and the most commercial anti-mastitis drugs are not able to penetrate the infected mammary sites and Staphylococcus aureus produces an enzyme that inactivates the most penicillins based treatment (Nickerson, 1993 and De-Oliveria et al., 2000). (c) In addition to the incurability and the chronic nature of staphylococcus aureus mastitis, this microorganism have the ability to live inside the invaded mammary cells (intercellular parasite) (Almeida et al., 2007) and to withstand strong inflammatory responses may be associated with an immune response mediated by factors secreted by Staphylococcus aureus (Sutra and Poutrel, 1994 and Almeida et al., 2007). (d) Moreover, numerous strains of Staphylococcus aureus of mastitis origin secrete a various powerful staphylococcal enterotoxins that secreted in milk of the mastitic udder causing serious problems for milk consumers (Tollersrud et al., 2006).

The current work revealed that the prevalence rate (\% affected) of gangrenous mastitis of the examined dairy buffaloes is comparatively low (9 of 89, 10.11\%). However, it appears to be the most terrible form of clinical mastitis caused by Staphylococcus aureus in buffaloes due to 
the severity of both local and systemic reactions of the affected animals. This severity may attribute to elaboration of a powerful necrotizing alpha toxin of Staphylococcus aureus inside the infected mammary tissues (Jubb et al., 1993). It was obviously noticed that the most common site of gangrenous lesion of the afflicted quarter at the annular fold (at the base of the teat). Such location could not be interpreted. However, this may be associated with the present of component of venous circle at the base of teat which drains erectile venous plexus in teat wall (Ashdowm and Done, 1984). On the other hand the unaffected neighboring quarters of gangrenous mastitis cases were found more reddish and warm. This may due to the diffusion of toxins through the vascular bed of the udder (Jubb et al., 1993).

Epizootiologically, all gangrenous mastitis caused by Staphylococcus aureus in buffaloes occurred shortly after calf-delivery. This possibly due to that during the preipartum period, the dairy animal experience certain alterations in defense mechanism associated with either changes in hormonal profile or metabolic and physiologic stresses (Mallard et al., 1998 and Oviedo-Boyso et al., 2006). Gangrenous mastitis occurred shortly after parturition in dairy cattle and goats (Jubb et al., 1993; Bezek and Hull, 1995 and Shibahara and Nakamura, 1999). Continuous diapedesis of sufficient amount of well-functioning neutrophils from blood into milk is a major obstacle to development of gangrenous mastitis associated with alpha toxin-producing Staphylococcus aureus (Schalm et al., 1976), and the number and the killing capabilities of polymorph nuclear cells in milk are reduced shortly after parturition (Kehrli et al., 1989a, Kehrli et al., 1989b and Weller and Davis, 1998). This may provide a tolerable account for the occurrence of gangrenous mastitis shortly after parturition.

The statistical analyses of the collected data elucidate that the prevalence rate of clinical mastitis of the examined buffaloes is primarily increased by increasing the lactation numbers till the third lactation season (peak infection rate, $10.99 \%$ ) and thereafter gradually decreased by subsequent increasing in the lactation numbers (range of infection rate, $8.45 \% \sim 2.70 \%$ ) and dairy buffaloes with more than 9 lactation seasons were found with no clinical signs of mastitis indicating a negative correlation relationship (correlation coefficient, $r=-0.92$ ), the correlation is significant at the 0.01 level. This highly significant $(P<0.01)$ negative correlation between the lactation numbers of the dairy buffaloes and prevalence of clinical mastitis may refer to a build-up of acquired immunity by subsequent lactation. Similar conclusion was 
reported by Bilal et al. (2004) who studied the factors affecting the prevalence of clinical mastitis in dairy buffaloes and revealed that the infection rate of clinical mastitis regressed by subsequent increase in lactation numbers. On the other side, the prevalence rate of clinical mastitis in multiparous buffaloes was mathematically higher than primiparous animals. However the statistical analyses (Chi square and one-way-ANOVA) revealed that there is no significant difference $(P>0.05)$.

During the period of investigation, the subsequent bacteriological examinations of the examined cases revealed that Staphylococcus aureus, Streptococcus agalactiae and Escherichia coli were the common mastitis pathogens of private dairy buffaloes. The ratio of isolation of Staphylococcus aureus (63.58\%): Streptococcus agalactiae (23.08 \%): Escherichia coli (7.69 \%) were approx. 8: 3: 1, and ratio of Streptococcus agalactiae: Staphylococcus aureus 1: 2.7. These ratios obviously elucidate that Staphylococcus aureus pathogen is becoming overwhelm in mastitis of private buffaloes. Conversely, Farid et al. (1975) revealed that Streptococcus agalactiae was the predominant mastitis pathogen of buffaloes, and their published results indicated that the ratio of Streptococcus agalactiae and Staphylococcus aureus was 1.44: 1. Such difference may ascribe to the high resistance rate of Staphylococcus aureus to the recent anti-mastitis therapy, in contrast to Streptococcus agalactiae (De-Oliveria et al., 2000). Moreover, results of rough questionnaire of the current work declared that the hygienic premilking precautions is unfortunately absent and the majority of the farmers have no expertise on postmilking dipping with an antimicrobial dip and dry period therapy at the end of lactation season. These play a pivotal role in existence and persistence of Staphylococcus aureusmastitis. Pre- and post-milking sanitary measures coupled with dry period therapy are the utmost point in declining the prevalence rate of contagious mastitis among dairy animal population (Bramley, 1996). Furthermore, results of the current questionnaire may refer to the lack of awareness and to the insufficient veterinary services in small villages.

\section{REFERENCES}

Ali, L.; Muhammed, G.; Arshad, M.; Saqib, M. and Hassan, I.J. (2008): Bacteriology of mastitis buffaloes in Tehsil Samundri of district Faisalabad, Pakistan. Pakistan Vet. J., 28, 1, 31-33. 
Almeida, R.A.; Patel, D.; Friton, G.M. and Oliver, S.P. (2007): Intracellular killing of mastitis pathogens by penethamate hydriodide following internalization into mammary epithelial cells. J. Vet. Pharmacol. Ther., 20, 2, 151-156.

Anderson, J.C. (1982): Progressive pathology of staphylococcal mastitis with a note on control, immunisaton and therapy, Vet. Rec. 110, 372-376.

Ashdowm, R.R. and Done, S. (1984): The Udder and Scrotum. In Color Atlas of Veterinary Anatomy. The Ruminants. Section 9, p 9.10. University Park Press, Gower Medical Publishing Ltd.

Bezek, D.M. and Hull, B.L. (1995): Peracute gangrenous mastitis and cheilitis associated with enterotoxin-secreting Staphylococcus aureus in a goat. Cand. Vet. J., 36, 106-107.

Bilal, M.Q.; Iqbal, M.U.; Muhammad, G.; Avais, M. and Sajid, M.S. (2004): Factors affecting the prevalence of clinical mastitis in buffaloes around Faisalabad (Pakistan). Int. J. Agri. Biol., 6, 1, $185-187$.

Bramley, A.J. (1996): Current concepts of bovine mastitis. National Mastitis Council, Madison, Wis.

Capurro, A.; Concha, C.; Nilsson, L.; Östensson, K. (1999): Identification of coagulase-positive staphylococci isolated from bovine milk. Acta Vet. Scand., 40, 315-321.

Chatfield, C. (1970): Regression and correlation. In Statistics for Technology. The $1^{\text {st }}$ Ed. Penguin Books Baltimore, Maryland. Pp. 166-199.

Cole, J.R.Jr. (1990): Micrococcus and Staphylococcus. In Diagnostic procedure of Veterinary Bacteriology and Mycology. $5^{\text {th }} \mathrm{Ed}$. Edited by Carter, G.R. and Cole, J. R. Jr. published by Charles $\mathrm{C}$ Thomas Publisher, Springfield Illinois, USA.

Deluyker, H.A.; Chester, S.T.; Oye, S.N. (1999): A multilocation clinical trial in lactating dairy cows affected with clinical mastitis to compare the efficacy of treatment with intramammary infusions of a lincomycin/neomycin combination with an ampicillin/cloxacillin combination. J. Vet. Pharmacol. and Ther. 22, 274-282.

De-Olveria, A.P.; Watts, J.L.; Salmon, S.A. and Aarestrup, F.M. (2000): Antimicrobial susceptibility of Staphylococcus aureus isolated from mastitis in Europe and the United State. J. Dairy Sci., 83, $855-862$. 
Detilleux, J.C. (2004): Neutrophils in the war against Staphylococcus aureus: predator-pery models to the rescue. J. Dairy Sci. 87, 11, 3716-3724.

El-Gamal, B.G.A. (1989): Studies on bacteria causing mastitis in cattle in Assiut. Ph D. Thesis. Faculty of Vet. Med., Assiut Univ.

Farid, A.; Abdel Ghani, M. and Oof, F. (1975): Bacterial and mycotic flora of apparently normal and mastitic buffaloe milk. Egypt. Vet. Med. J., 23, 295-306.

Haltia, L.; Buzalski, T.H.; Spiridonova, I.; Olkonen, A. and Myllys, V. (2006): A study of bovine mastitis, milking procedures and management practices on 25 Estonian dairy herds. Acta Vet. Scand. 48, 22. Cited by http://www.actavetscand.com/content/48/1/22.

Jubb, K.V.F.; Kennedy, P.C. and Palmer, N. (1993): The mammary glands. In Pathology of Domestic Animals, $4^{\text {th }}$ Ed. Vol. 3, Academic Press. Pp 454-470.

Kehrli, M.E.; Nonneche, B.J. and Rothm, J.A. (1989a): Alterations in bovine neutrophil function during the perparturition period. Am. J. Vet. Res. 50, 2, 207 - 214.

Kehrli, M.E.; Nonneche, B.J. and Rothm, J.A. (1989a): Alterations in bovine lymphocyte function during the perparturition period. Am. J. Vet. Res. 50, 2, 215-220.

Mallard, B.A.; Dekkers, J.C.; Ireland, M.J.; Leslie, K.E.; Sharif, S. and Vankampen, C.L. (1998): Alteration in immune responsiveness during the peripartum period and its ramification on dairy cow and calf health. J. Dairy Sci., 81, 585-595.

Metry, (1996): Buffalo. The main dairy animal in Egypt. Booklet, Academy of Scientific Research and Technology.

Milton, J.S. and Tsokos, J.O. (1983): Statistical Methods in Biological and Health Science. International student Edition. McGrawHill International Book Co.

Newbould, F.H.S. (1990): Bovine mastitis. In Diagnostic procedure of Veterinary Bacteriology and Mycology. $5^{\text {th }}$ Ed. Edited by Carter, G.R. and Cole, Jr. Charles C Thomas Publisher, Springfield Illinois, USA.

Nickerson, P.C. (1993): Eliminating chronic staphylococcal mastitis. Vet. Med., 88, 375-381. 
Oviedo-Boyo, J.; Valdez-Alarcon, J.J.; Cajero-Juarez, M.; OchoaZarzosa, A.; Lopez-Meza, J.E.; Bravo-Patino, A. and BaizabalAguirre, V.M. (2006): Innate immune response of bovine mammary gland to pathogenic bacteria responsible for mastitis. Journal of Infection, 54, 399-409. Cited by www. elsevierhealth.com/journals/jinf

Owens, W.E.; Ray, C.H.; Watts, J.L. and Yancey, R.J. (1997): Comparison of success of antibiotic therapy during lactation and results of antimicrobial susceptibility tests for bovine mastitis. J. Dairy Sci., 80, 313-317.

Palanivel, K.M.; Prabakar, T.G.; Selvasubramanian, S. and Vijayalingam, T.A. (2008): Epidemiology of bovine mastitis in and around Chennai. Indian Journal of Field Veterinarians. 2008; 3(3): 24-27

Pyörala, S. and Pyörala, E. (1997): Accuracy of methods using somatic cell count and $\mathrm{N}$-acetyle-beta-D-glucosaminidase activity in milk to assess the bacteriological cure of bovine clinical mastitis. J. Dairy Sci. 80, 2820-2825.

Reddy, P.; Qi, C.; Zembower, T.; Noskin, G.A. and Bolon, M. (2007): Postpartum mastitis and community-acquired methicillinresistant Staphylococcus aureus. Emerg. Infect. Dis., 13 2, 298-301.

Riekerink, G.M.; Barkema, H.W.; Veenstra, S.; Poole, D.E.; Dingwell, R.T. and Keefe, G.P. (2006): Prevalence of contagious mastitis pathogens in bulk tank milk in Prince Edward Island. Can. Vet. J., 47, 567-572.

Riffson, R.; Sayaith, K.; Khalil, H.; Dubreuil, P.; Drolet, M. and Lagace, J. (2001): Development of a rapid and sensitive test for identification of major pathogen in bovine mastitis by PCR. J Clinical Microbiol. 39, 7, 2584-2589.

Seddek, S.R.; Abd El-Kader, H.A. and Abd El-Hafeez, M.M. (1999): Bacteriological studies of subclinical mastitis in Friesian cattle in Assiut Governorate. Assiut Vet. Med. J., 42, 83, 77-88.

Schalm, O.W.; Lasmanis, J. and Jain, N.C. (1976): Conversion of chronic staphylococcal mastitis to acute gangrenous mastitis after neutropenia in blood and bone marrow produced by an equine antibovine leukocyte serum. Am. J. Vet. Res., 37, 8, 885-890. 
Shibahara and Nakamura (1999): Pathology of acute necrotizing mastitis casused by Staphylococcus aureus in a dairy cow. Jap. Agric. Res. Q. (JARQ), 33, 2, 139-142.

Sutra, L. and Poutrel, B. (1994): Virulence factors involved in the pathogenesis of bovine intramammary infections due to staphylococcus aureus. J. Med. Microbiol., 40, 79-89.

Tollersrud, T.; Kampen, A.H. and Kenny, K. (2006): Staphylococcus aureus entrotoxin D is secreted in milk and stimulates specific antibody responses in cows in the course of experimental intramammary infection. Infection and Immunity, 74, 6, 3507-3512.

Waage, S.; Skei, H.R.; Rise, J.; Rogdo, T.; Sviland, S. and Odergaard, S.A. (2000): Outcome of clinical mastitis in dairy heifers assessed by reexamination of cases one month after treatment. J. Dairy Sci., 83, 70-75.

Weller, R.F. and Davis, D.W. (1998): Somatic cell count and incidence of clinical mastitis in organic milk production. Vet. Rec., 143, $13,365-366$. 
Assiut Vet. Med. J. Vol. 54 No. 119 October 2008
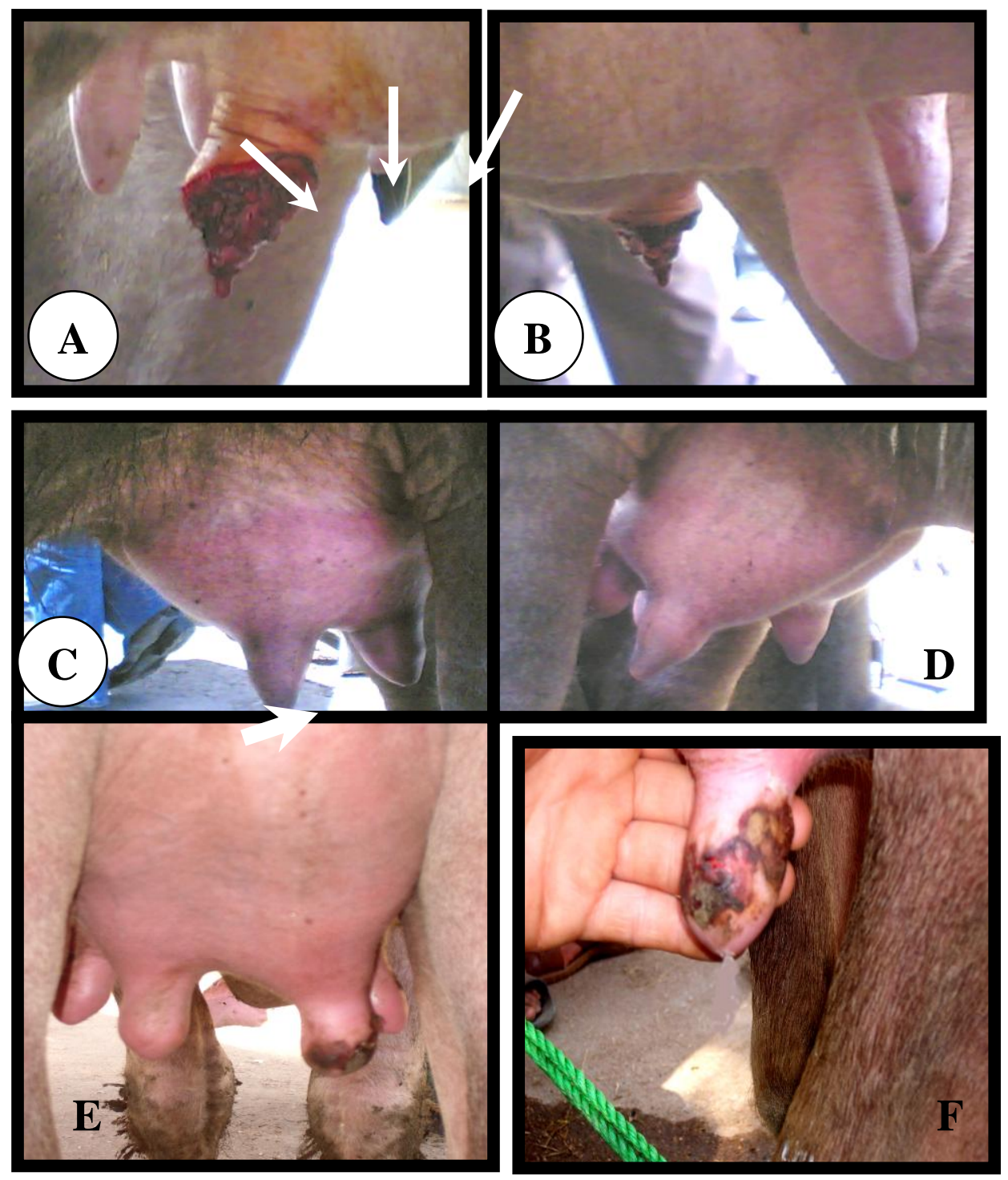
Assiut Vet. Med. J. Vol. 54 No. 119 October 2008
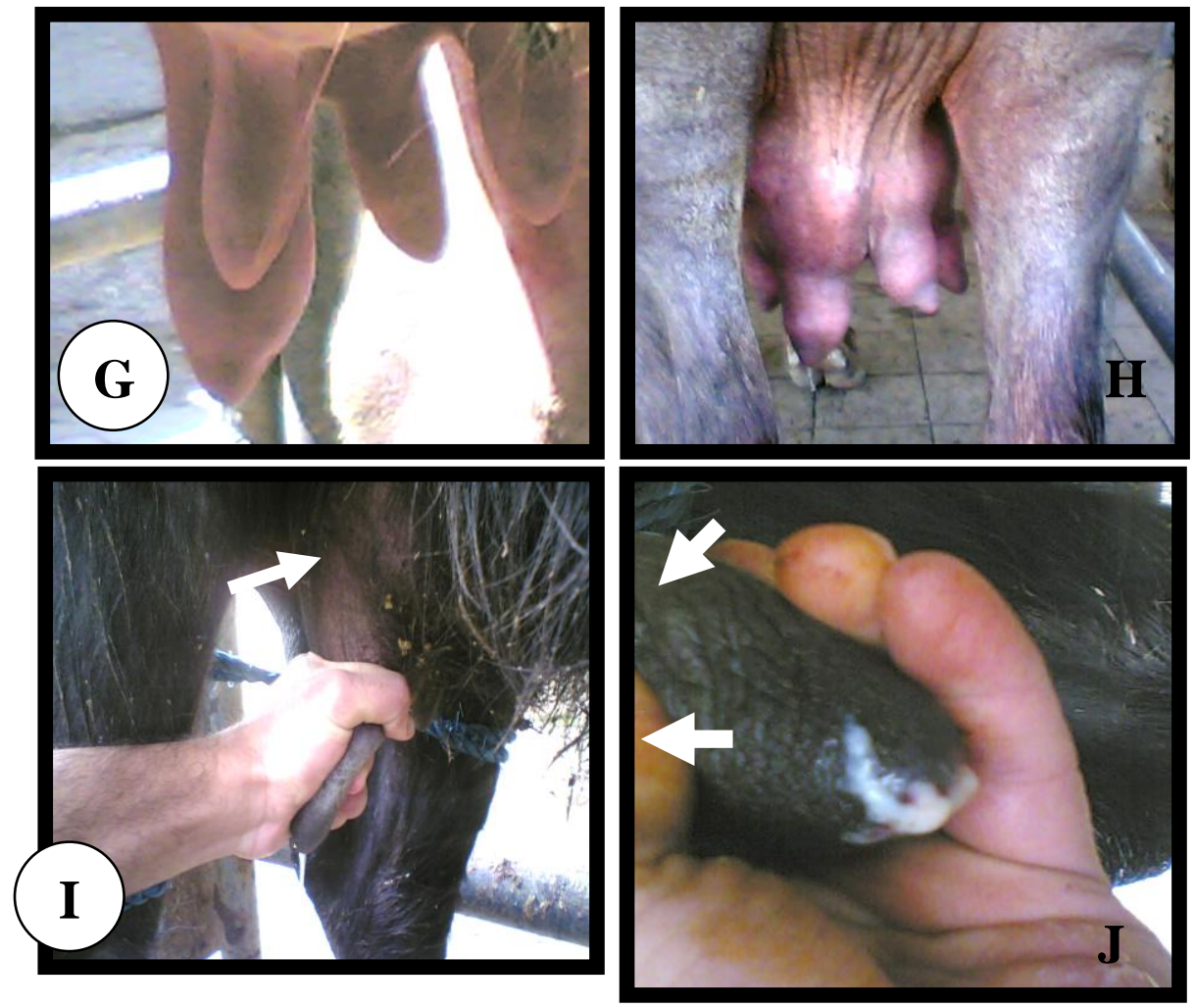